\section{Sammenheng mellom tarmflora, fedme og diabetes?}

\author{
Høye nivåer av bakteriebestanddeler målt i blodet er sterkt assosiert \\ med fedme og diabetes. Dette viser en norsk studie.
}

En norsk forskergruppe har funnet en sterk assosiasjon mellom mengden av bakteriebestanddelen lipopolysakkarid målt i plasma og mengde innvollsfett, lipidverdier og blodsukkernivå. Resultatene er nylig publisert i tidsskriftet Diabetes Care (1).

Studien omfattet 49 overvektige pasienter som gjennomgikk laparoskopisk fedmekirurgi (gastrisk bypass eller duodenal omkobling). Kontrollgruppen besto av 17 personer med BMI $<28$ som gjennomgikk elektiv laparoskopisk galleveiskirurgi. Lipopolysakkaridnivå i plasma, $\mathrm{HbA1c}$ og triglyserider ble målt før og ett år etter operasjon. Mengde fettvev ble beregnet ved CT-undersøkelse før operasjonen. Fettvevsbiopsier fra ulike typer fettvev ble tatt under operasjonen, og bakterielt DNA ble kvantitert i fettvevsbiopsiene.

Preoperativt var lipopolysakkaridnivået høyere hos dem som skulle fedmeopereres sammenliknet med kontrollgruppen, og det var en sterk korrelasjon mellom lipopolysakkaridnivå og både HbAlc-nivå, triglyseridnivå og mengde innvollsfett. Korrelasjonen til mengden underhudsfett var moderat. Det var en fallende gradient i mengde bakterielt DNA i fettvev ved økende avstand til tarmen, med bare halvparten så høyt nivå i underhudsfettet som i mesenterielt fettvev.

Lipopolysakkaridnivået gikk signifikant ned etter fedmekirurgi. Det var en nesten direkte korrelasjon mellom nedgang i lipopolysakkaridnivå og reduksjon i både triglyseridnivå og HbA1c postoperativt.

- Lipopolysakkarid produseres først og fremst av tarmbakterier, og hypotesen er at lipopolysakkarid og andre mikrobielle produkter lekker fra tarmen over til blodbanen og innvollsfettet, forteller Marius Trøseid som er førsteforfatter på den omtalte studien. - Det er vist i dyreforsøk at fettrik kost gir en mer permeabel tarmslimhinne. Vi tenker oss at lipopolysakkarid stimulerer en lavgradig inflammasjon ved å trigge tolliknende reseptorer i immunceller i fettvev og blodårevegg.

- Resultatene er forenlige med andre studier som har funnet en sammenheng mellom sammensetning av tarmflora og utvikling av fedme. I dyreforsøk er det også vist at lipopolysakkarid i seg selv kan indusere fedme, insulinresistens og diabetes, og at denne effekten dramatisk reduseres om man blokkerer lipopolysakkaridreseptoren CD14. Fremtiden vil vise om tarmslimhinnen, tarmfloraen, lipopolysak-

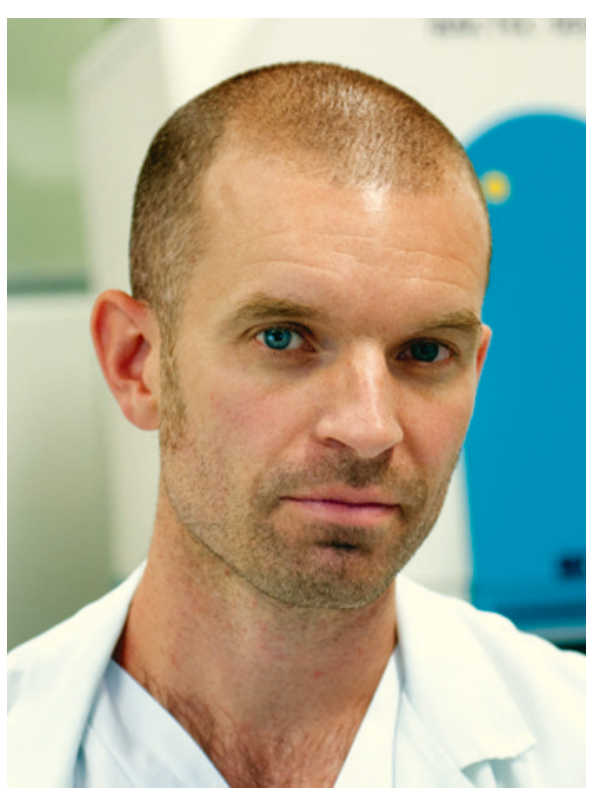

Marius Trøseid. Foto privat

karid eller andre mikrobielle produkter kan manipuleres for å forebygge og behandle fedme og diabetes, sier Trøseid.

\section{Forskningssamarbeid}

Studien er gjennomført i samarbeid mellom Marius Trøseid ved Infeksjonsmedisinsk avdeling, Oslo universitetssykehus og Torunn Nestvold og medarbeidere ved Nordlandssykehuset i Bodø. Seniorforfatter er professor Knut Tore Lappegård ved Indremedisinsk avdeling ved Nordlandssykehuset. Gastrokirurg Nestvold har rekruttert og operert samtlige pasienter. Ideen til dette konkrete delprosjektet sprang ut fra Trøseids tidligere forskning, der han fant at subklinisk tarmskade og forhøyet lipopolysakkaridnivå ser ut til å spille en viktig rolle for sykdomsprogresjon ved hivinfeksjon og muligens for kardiovaskulær risiko. Forfatterne har også tidligere publisert sammen rundt temaet metabolsk syndrom, kardiovaskulær risiko og inflammasjonsmarkører.

\section{Hanne Støre Valeur}

hanne.store.valeur@legeforeningen.no Tidsskriftet

\section{Litteratur}

1. Trøseid M, Nestvold TK, Rudi K et al. Plasma lipopolysaccharide Is closely associated with glycemic control and abdominal obesity: Evidence from bariatric surgery. Diabetes Care 2013; e-publisert 8.7.2013.
Ordforklaringer

Lipopolysakkarid eller endotoksin: Bakteriebestanddel på overflaten av gramnegative bakterier. Stimulerer tolliknende reseptor 4 og er en viktig årsaksfaktor til vasodilatasjon og sjokkutvikling ved gramnegativ sepsis. Lipopolysakkaridnivåene som er målt i denne studien ligger på et mye lavere nivå enn ved sepsis.

Tarmflora: Tarmfloraen inneholder anslagsvis ti ganger så mange celler og minst 150 ganger så mange gener som kroppen for øvrig, og blir nå kartlagt gjennom det såkalte Human microbiota project. Flere studier viser at endringer i tarmfloraen er assosiert med en lang rekke sykdomsprosesser. Stadig nye sekvenseringsteknologier gjør at studier av tarmfloraen er et raskt ekspanderende forskningsfelt.

Fedmekirurgi: Kirurgiske inngrep som blir utført som et ledd i behandlingen av pasienter med sykelig overvekt. Operasjonene som er utført i denne studien er laparoskopisk gastrisk bypass og bileopankreatisk diversjon med duodenal omkobling.

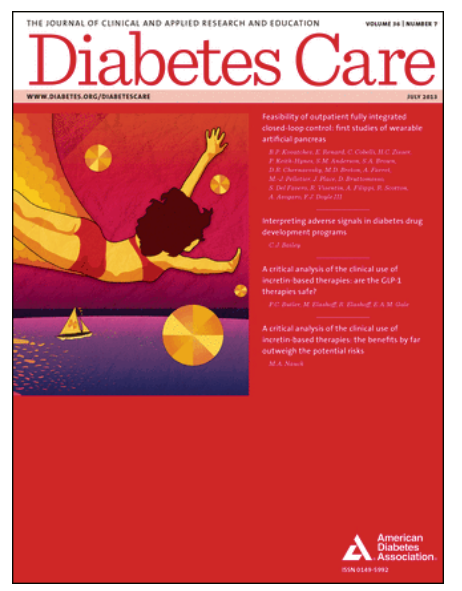

Artikkelen ble publisert juli 2013 i tidsskriftet Diabetes Care, som er det høyest rangerte tidsskriftet innen klinisk diabetesforskning 